\title{
Simulation of the use of a heat accumulator in combined heat and power plants
}

ABSTRACT: The sustainable management of energy production and consumption is one of the main challenges of the $21^{\text {st }}$ century. This results from the threats to the natural environment, including the negative impact of the energy sector on the climate, the limited resources of fossil fuels, as well as the unstability of renewable energy sources - despite the development of technologies for obtaining energy from the: sun, wind, water, etc. In this situation, the efficiency of energy management, both on the micro (dispersed energy) and macro (power system) scale, may be improved by innovative technological solutions enabling energy storage. Their effective implementation enables energy storage during periods of overproduction and its use in the case of energy shortages.

These challenges cannot be overestimated. Modern science needs to solve various technological issues in the field of storage, organizational problems of enterprises producing electricity and heat, or issues related to the functioning of energy markets.

The article presents the specificity of the operation of a combined heat and power plant with a heat accumulator in the electricity market while taking the parameters affected by uncertainty into account. It was pointed out that the analysis of the risk associated with energy prices and weather conditions is an important element of the decision-making process and management of a heat and power plant equipped with a cold water heat accumulator. The complexity of the issues and the number of variables to be analyzed at a given time are the reason for the use of advanced forecasting methods. The stochastic modeling methods are considered as interesting

\footnotetext{
${ }^{1}$ AGH University of Science and Technology, the Faculty of Geology, Geophysics and Environmental Protection; e-mail: pjastrze@agh.edu.pl

${ }^{2}$ AGH University of Science and Technology, the Faculty of Management; e-mail: psaluga@zarz.agh.edu.pl
} 
tools that allow forecasting the operation of an installation with a heat accumulator while taking the influence of numerous variables into account. The analysis has shown that the combined use of Monte Carlo simulations and forecasting using the geometric Brownian motion enables the quantification of the risk of the CHP plant's operation and the impact of using the energy store on solving uncertainties. The applied methodology can be used at the design stage of systems with energy storage and enables carrying out the risk analysis in the already existing systems; this will allow their efficiency to be improved. The introduction of additional parameters of the planned investments to the analysis will allow the maximum use of energy storage systems in both industrial and dispersed power generation.

KEYWORDS: energy production, energy storage, consumption forecasting, Monte Carlo simulation

\section{Introduction}

Global economic growth and technological development are the reasons for an increased demand for energy - both electricity and heat. While increasing energy production is limited by the depletion of fossil fuel resources, the production based on these fuels results in irreversible ecological consequences. The consequence of actions taken is the adoption of system solutions aimed at the reasonable and sustainable management of fossil fuels, reducing the negative impact of the energy industry on the environment, and the rational energy economy; this can also be obtained by reducing consumption. The development of modern production technologies, including, among others, renewable energy sources, has a significant impact on the situation on the energy market. However, they have a significant disadvantage - the mentioned sources, despite increasing the efficiency of the installation, are characterized by unstable operation. The production of energy from RES largely depends on atmospheric conditions, which can contribute to both excess electricity produced and shortages in times of increased energy demand. Therefore, the energy industry is still based on conventional sources including fossil fuels and on nuclear power plants, despite the fact that some developed countries (e.g. Germany) have abandoned their nuclear programs after the Fukushima Daiichi nuclear disaster in 2011. The depleting resources of fossil fuels and the unstability of renewable energy sources, including the changing energy demand depending on atmospheric conditions or industry demand, have resulted in a large-scale studies of the possibilities of storing excess energy produced and using it during periods of increased demand (Graus et al. 2011). 


\section{Energy storage}

Energy production involves the use of fossil fuels, renewable sources, or nuclear fuels and their conversion into kinetic, potential, electrical, and heat energy (Fig. 1). This energy can be stored in storage systems including, among others, flywheels, pumped storage power plants, batteries, reversible fuel cells, or heat or cold storage tanks (Wojciechowski 2017).

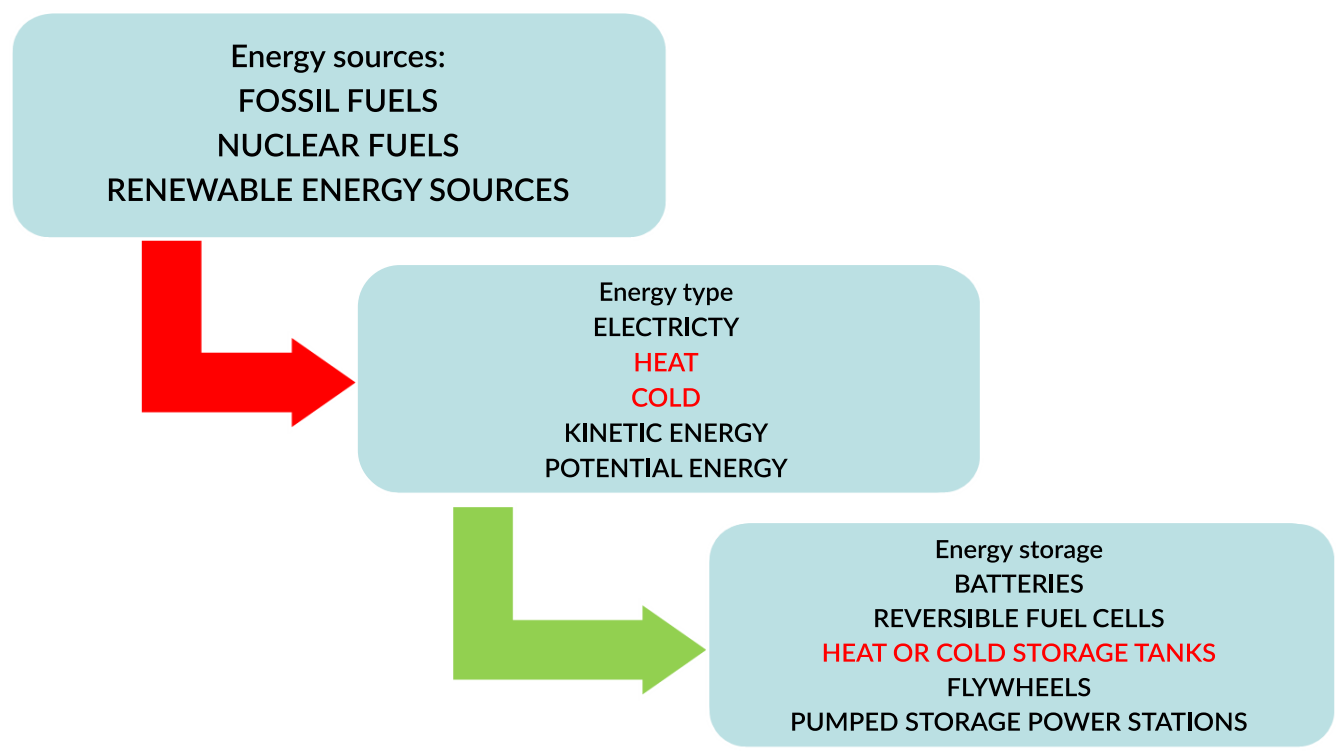

Fig. 1. Primary energy sources, energy conversion and storage (Wojciechowski 2017)

Rys. 1. Źródła energii pierwotnej, ich konwersja i magazynowanie

Almost 50\% of energy consumed in Poland is heat energy (Central Statistical Office of Poland 2017). At the same time, it is the main type of energy consumed in households - over $80 \%$ of the energy is used for heating and hot tap water.

For this reason, heat storage systems, the classification of which is shown in Fig. 3, are currently widely used in the micro scale in distributed (Basecq et al. 2013) and individual installations, households (Nuytten et al. 2013) collective heating systems, and the municipal sector (Parra et al. 2017). The growing energy consumption and the volatility of the market situation were the reasons behind the interest of the industrial power sector in heat accumulators (Droste-Franke et al. 2012). The use of heat accumulators is particularly effective, due to the ability to operate in cogeneration plants, in the case of CHP plants. 


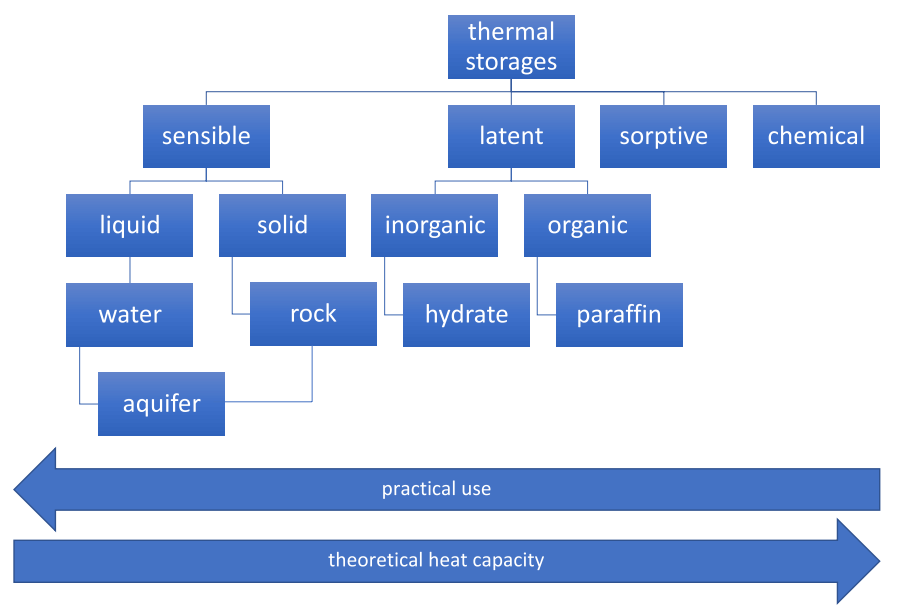

Fig. 2. Classification of energy storage systems in terms of physical parameters (Fisch et al. 1992)

Rys. 2. Klasyfikacja magazynów ciepła w zależności od parametrów fizycznych

\section{Energy production in CHP plants}

Heat is generated as a result of the chemical conversion of fuel in a steam boiler, where it serves to heat and evaporate the water and to superheat the generated steam, the energy of which is transformed in the turbine into mechanical energy and passed, through the drive shaft, to the electricity generator. The production of electricity in a traditional condensing power plant is characterized by low generation efficiency (below $40 \%$ ) due to the generation of waste heat that is not used (Szramka 2001). Thanks to the use of modern technologies, this efficiency can be raised to around $55 \%$.

A higher efficiency of energy production (over 75\%) is obtained by cogeneration units, meaning combined heat and power (CHP) plants. The efficiency of energy production in cogeneration systems is shown in Fig. 3. In the above mentioned plants, waste heat, which is irretrievably lost in the case of conventional power plants, can be used for heating. It is used to increase the temperature of water in district heating systems or for the heating of utility water. In addition, the steam expanded in the turbine can also be used as a technological medium.

Cogeneration or combined heat and power (CHP) is therefore the production of electricity and heat in a single process using the same fuel for two different uses. From the point of view of economics, the combined heat and power generation is a transformation of the stream of investment outlays and operating costs into the stream of revenues from the sale of electricity and heat. 


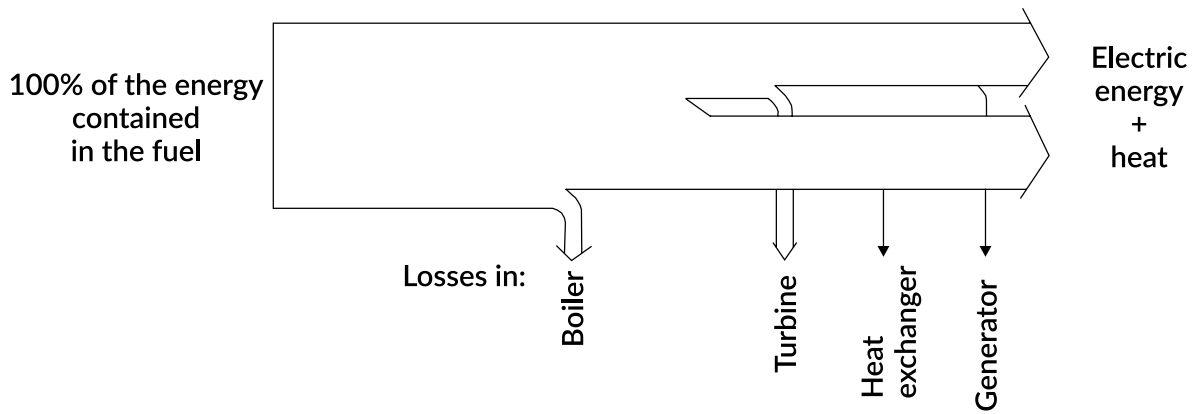

$70-85 \%$

Fig. 3. The efficiency of energy production in cogeneration units (Paska 2005)

Rys. 3. Efektywność produkcji energii w kogeneracji

\section{The operation of combined heat and power plants in the energy market}

Due to the specificity of energy production in cogeneration systems, i.e. the production of both electricity and heat, combined heat and power plants operate in two energy markets and thus under different conditions at the same time.

Heat production and trading is a regulated market and subject to statutory restrictions. The Energy Law act obliged, among others, the producers of heat to ensure the continuity of supply; at the same time district heating tariffs are regulated by the President of the Energy Regulatory Office. Therefore, companies cannot set heat prices and are obliged to ensure adequate production regardless of market conditions. In turn, the energy demand is dependent on weather conditions, such as outdoor temperature, insolation, or wind speed. These conditions are subject to uncertainty, which could be a risk in the operation of CHP plants. Furthermore, back pressure turbine cogeneration systems (such a system is more efficient compared to a condensing turbine) are associated with operational restrictions related to the simultaneous production of electric energy and heat.

CHP plants are interested in producing as much electricity as possible while giving priority to heat generation. The question of electricity production is particularly important when a combined heat and power plant can sell it with a profit in the balancing market. The price of electricity on the balancing market is difficult to predict.

Favorable prices in the balancing market allow additional electricity sales from CHP plants. It should be noted that the production of additional electricity is not always possible due to limitations resulting from: 
- The heat market (obligation to ensure heat supply),

- Production technology (in the case of reduced heat demand, heat and power plants need to reduce electricity production).

The technological solution in the situation of imbalance in the production of electricity and heat in a CHP plant is the use of heat accumulators, which can:

- Store the excess heat produced in cogeneration systems that cannot be transferred to district heating,

$\downarrow$ Use the energy stored in the accumulator in the case of energy shortage.

\section{The simulation of the use of a heat accumulator in combined heat and power plants}

\subsection{The model of the CHP plant's production control system}

As mentioned above, the operation of the combined heat and power plant as a system (Fig. 4) is subject to constant disturbances.

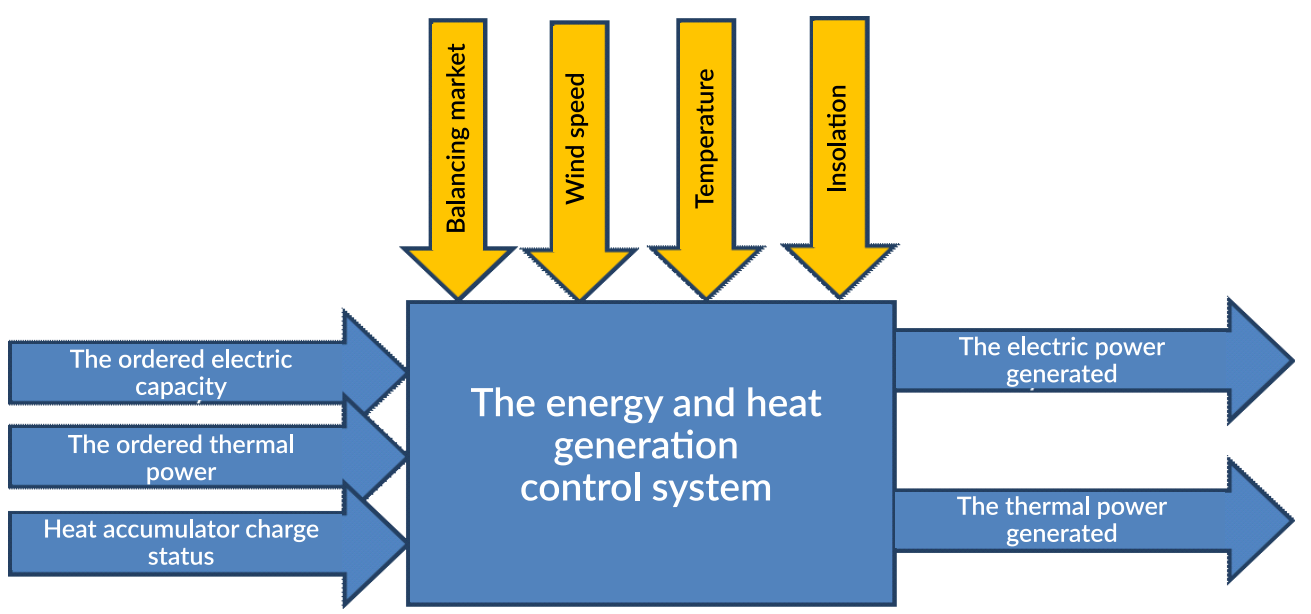

Fig. 4. The energy and heat generation control system (own study)

Rys. 4. Schemat systemu sterowania produkcją elektrociepłowni

The input signals of the subject system are:

$\checkmark$ The ordered (for example, by a sales company) electric capacity, which, in accordance with the demand schedule, the CHP plant is obliged to supply to the power grid, 
\ The thermal power ordered by a heating company (the transmission system operator),

$\downarrow$ Heat accumulator charge status.

In turn, the output signals are:

- The electric power generated, which is supplied to the grid,

$\downarrow$ The thermal power produced, which is supplied to the district heating network. As emphasized, the system is influenced by external factors - understood as disturbances:

$\checkmark$ The situation on the balancing market (additional electricity production and sales in case of an electricity shortage),

$\checkmark$ Atmospheric conditions (wind speed, insolation, and outside temperature), which affect the heat consumption by the district heating network operator; wind-chill, which has a direct impact on the level of thermal comfort and increase or decrease in heat demand, is also dependent on the atmospheric conditions.

Interfering signals are stochastic and associated with a risk. Therefore, in order to ensure the efficient operation of the CHP plant, the proper use of the accumulator, which allows for the risk caused by a high level of interference signals related to atmospheric conditions or the situation in the balancing market to be minimized, is required.

The objective function is defined as the maximization of electricity generation - i.e. the increase in the production of additional energy to the balancing market:

$$
f(x)=\max \text { Qerb }
$$

The decision-making process is hindered by the following obstacles:

$$
\text { Qemin } \leq \text { Qerb } \leq \text { Qemax }
$$

$$
\text { Qemax }<0,5 \text { Qtmax }
$$

$$
\text { Qtmin }<Q t z<Q t \max
$$

$$
\text { Qtmin }<\text { Qto }<\text { Qtmax }
$$

Where:

Qemin - minimum electrical energy produced in cognereation,

Qemax - maximum electrical energy produced in cognereation,

Qtmax - maximum amount of heat produced in cogeneration,

Qtmin - minimum amount of heat produced in cogeneration,

Qtz - ordered heat,

Qto - collected heat. 


\subsection{The applied methods of risk assessment}

The risk assessment is usually carried out with the use of:

$\downarrow$ Sensitivity analysis, where the influence of a single parameter - the explanatory variable (e.g. price changes on the balancing market) on the explained variable (the final result of the simulation) is examined,

$\downarrow$ Scenario analysis, with specific levels of several key parameters are assumed for various event variants, while their impact on the explained variable (simulation results) is examined,

- Stochastic analyses, where statistical methods using probability distributions of the expected value of the analyzed parameters are used to examine the behavior of the model and the statistics of the final result.

In the discussed simulation of the use of heat accumulator, the Monte Carlo simulation (Prieto et al. 2018) and geometric Brownian motion (Deb et al. 2017), used to model prices, were used.

The main parameters of the calculation:

$\checkmark$ The contracted capacity (thermal power),

$\checkmark$ The contracted capacity (electric power),

$\checkmark$ The air temperature,

were introduced into the model in the form of probability distributions created on the basis of historical data covering the period analogous to the analyzed one - i.e. hourly distribution in two selected weeks of the year. The simulation process correlated the forecasted outdoor temperature with the predicted thermal power received by the grid operator (the correlation coefficient of -0.8 ), which results from the fact that an increase in the outside temperature (e.g. an increase in insolation) reduces the heat demand of consumers.

At the same time, the energy price on the balancing market and the Polish Power Exchange was modeled, as mentioned, with the use of geometric Brownian motion based on historical data from the two weeks preceding the analyzed period.

Two variants of the CHP plant's operation were analyzed:

1. The option without energy storage - the produced heat can be transferred only to district heating.

2. The variant using a low temperature heat accumulator, where, depending on the accumulator mode, the energy surplus / shortage can be transferred to/from the accumulator.

To estimate the results of Monte Carlo simulation, 10,000 iterations were used, which was sufficient for the stability of the resulting distribution of values.

To illustrate the results, the limit value of additional energy sales in the balancing market at a level of $100 \mathrm{MWh}$, which is approximately twofold higher than the average production of the combined heat and power plant without the heat accumulator, was adopted. 


\section{The analysis of the obtained results}

As a result of the simulation, the probability of meeting the electricity demand of the balancing market, with and without the heat accumulator, was determined.

Fig. 5 shows the graph of the probability density (histogram) of obtaining the expected value of the volume of energy for the variant without a battery, while Fig. 6 shows a graph of the cumulative distribution function.

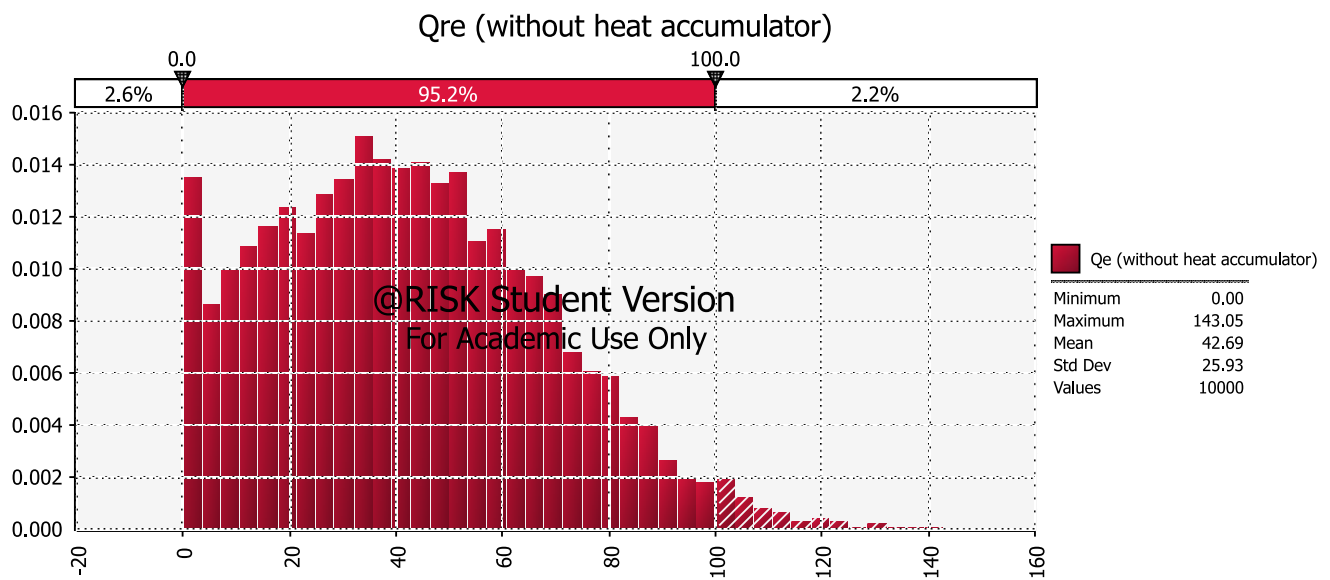

Fig. 5. The probability density (histogram) of the expected electricity production - option without the heat accumulator

Rys. 5. Gęstość prawdopodobieństwa wartości oczekiwanej dla wariantu bez akumulatora

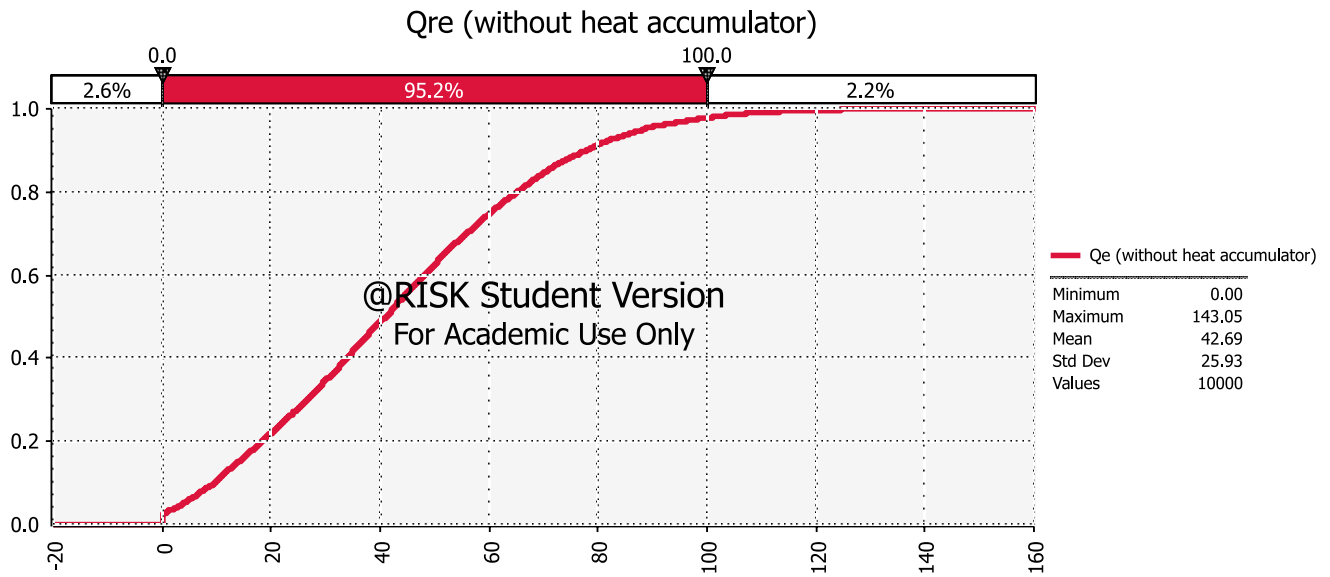

Fig. 6. The distribution of the expected electricity production - option without the heat accumulator

Rys. 6. Dystrybuanta wartości oczekiwanej dla wariantu bez akumulatora 
In the variant without the heat accumulator, the probability of reaching the adopted limit value of the electricity production for the balancing market is only $2.2 \%$, which limits the operations of the combined heat and power plant to the contract market. The attempt to act as an active player in the energy market is associated with a high risk of failure to achieve the assumed parameters.

A different situation occurs when a low temperature energy storage system (in the form of water heat accumulator) is implemented in the combined heat and power plant's production system. Fig. 7 shows the probability density histogram of the expected value of electricity production obtained as a result of the simulation, while Figure 8 - the distribution of the expected distribution. It is clearly visible that the risk of not achieving the assumed energy production in the case of variant with a heat accumulator is only $5.1 \%$.

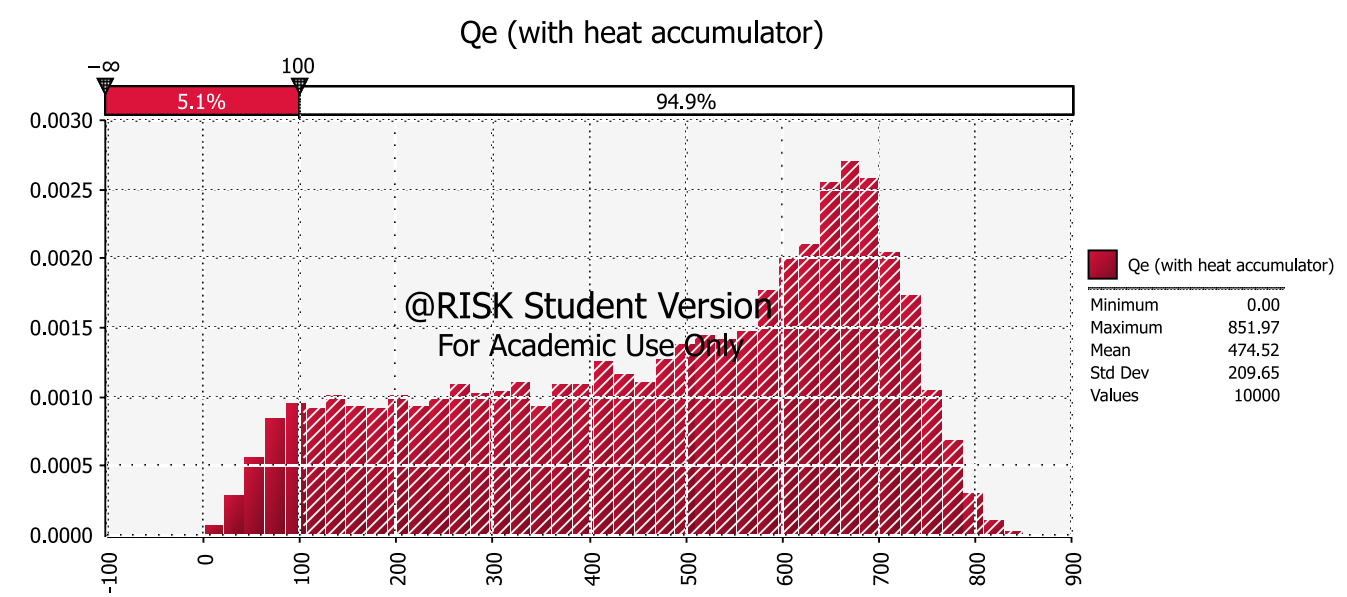

Fig. 7. The probability distribution (histogram) of the expected electricity production - option with the heat accumulator

Rys. 7. Wykres gęstości prawdopodobieństwa wartości oczekiwanej wielkości produkcji energii elektrycznej dla wariantu z zastosowanym akumulatorem ciepła

Below, Table 1 summarizes the simulation results for variants without and with the heat accumulator.

In the case of the maximum values, the production with the use of a battery is almost six fold higher than without the heat accumulator; for medium values it is over 10 times higher.

Taking the price of $1 \mathrm{MWh}$ (as mentioned earlier, estimated in the model using geometric Brownian motion based on historical data from the 14 day period preceding the surveyed period) at the level of 159.65 PLN/ MWh into account, the additional revenue of the CHP plant using the heat accumulator from energy sales in the balancing market is estimated in the range from PLN 1.15 thousand to PLN 141.04 thousand (PLN 76.55 thousand on average). When comparing the obtained values with the revenues of the CHP plant without the energy storage system, 


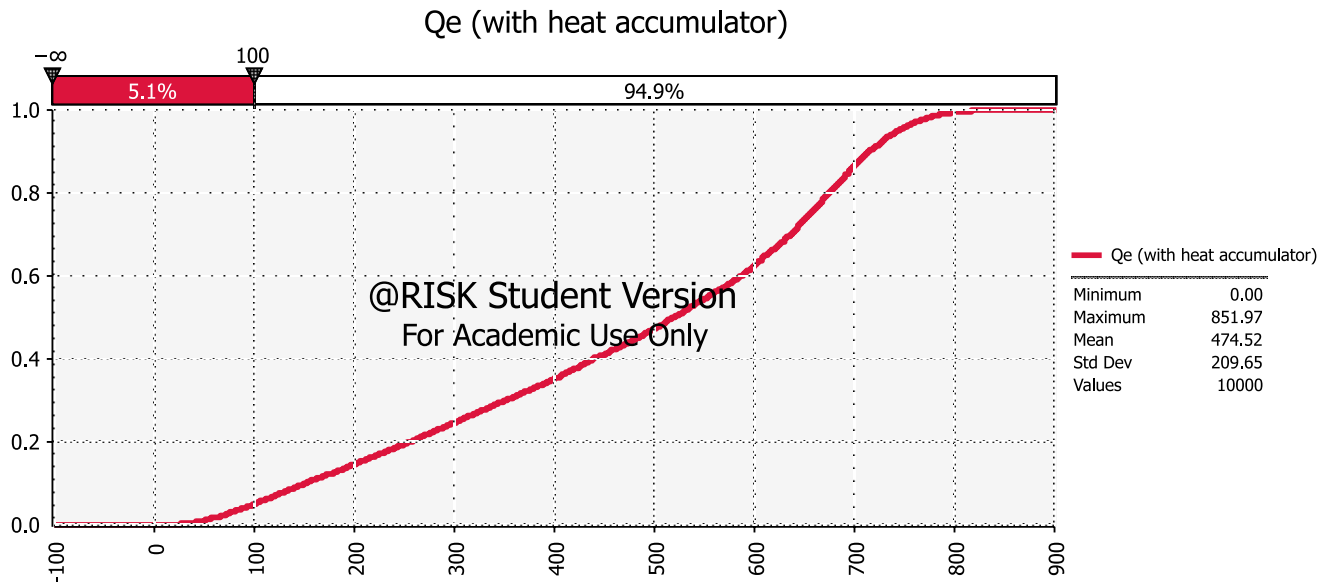

Fig. 8. The distribution of the expected electricity production - option with the heat accumulator

Rys. 8. Dystrybuanta wielkości energii elektrycznej produkowanej z zastosowaniem akumulatora ciepła

TABLE 1. The results of Monte Carlo simulation of the electricity production for both options - without and with the heat accumulator

TABELA 1. Zestawienie wyników symulacji wielkości produkcji energii elektrycznej w wariancie bez i z akumulatorem ciepła

\begin{tabular}{|l|c|c|}
\hline The electricity produced $[\mathrm{MWh}]$ & With the heat accumulator & Without the heat accumulator \\
\hline Minimum & 7.25 & 0.00 \\
\hline Maximum & 883.41 & 143.05 \\
\hline Mean & 479.50 & 42.69 \\
\hline Standard deviation & 210.01 & 25.93 \\
\hline
\end{tabular}

the difference in revenues varies from PLN 1.1 thousand to PLN 69.7 thousand. Therefore, for maximum values, the use of the accumulator increases the revenues by nearly $620 \%$, while for average values an increase of about $1000 \%$ can be observed.

\section{Conclusions}

The operation of the combined heat and power plant is associated with the risk resulting from the situation on the energy market and the uncertainty caused by atmospheric conditions that affect the heat demand. Wind, temperature, insolation, and electricity prices have a direct impact 
on the profitability of energy production. The effective management of the operation of a plant producing both electricity and heat requires an analysis of the market situation. Risks associated with fluctuations in electricity demand, while operating in a regulated heat market, can be minimized by using energy storage systems. Accumulators allow for storing excess energy produced and using it during periods of increased demand. At the same time, they allow for maximizing the electricity production in the case of an insufficient demand for heat when generated in cogeneration systems (back pressure turbines), which in turn allows revenues from electricity sales to be increased. It is also worth noting that the use of energy storage allows for the more efficient use of fossil and renewable energy sources, which, in turn, reduces environmental impacts of the power sector. The use of stochastic methods for assessing the operational risk of a combined heat and power plant enables designing operation parameters and a real-time analysis of the situation. The use of Monte Carlo simulation in modeling the operation of a combined heat and power plant allows the market situation to be analyzed while taking the dynamically changing input data and thus, the current risk assessment, into account. The Monte Carlo simulation used in forecasting the operation of heat accumulators allows for planning and optimizing the capacity of heat storage systems already at the installation design stage.

\section{References}

BASECQ et al. 2013 - BASeCq, V., MichauX, G., InARD, Ch. and BlondeaU, P. 2013. Short-term storage systems of thermal energy for buildings: a review. Advances in Building Energy Research (ABER) 7(1), pp. 66-119.

Deb et al. 2017 - Deb, C., Zhang, F., YANG, J., LeE, S.E. and ShaH, K.W. 2017. A review on time series forecasting techniques for building energy consumption. Renewable and Sustainable Energy Reviews. Elsevier Ltd., 74 (July 2016), pp. 902-924.

Droste-Franke et al. 2013 - Droste-Franke, B., PAal, B.P. and Rehtanz, C. 2013. Balancing Renewable Electricity: Energy Storage, Demand Side Management, and Network Extension from an Interdisciplinary Perspective.

Central Statistical Office 2017 - Energia 2017, p. 28 (in Polish).

GraUs et al. 2011 - GrAUS, W., BlOMEN, E. and WORRELL, E., 2011. Global energy efficiency improvement in the long term: A demand - and supply-side perspective. Energy Efficiency 4(3), pp. 435-463.

NuYtten et al. 2013 - NuYtTEn, T., Claessens, B., PAREDis, K., BAElAB, J. and SiX, D. 2013. Flexibility of a combined heat and power system with thermal energy storage for district heating. Applied Energy vol. 104, pp. 583-591.

Parra et al. 2017 - Parra, D., Swierczynski, M., Stroe, D., Normaln, S., Abdond, A., WorlitSCheK, J., O’Doherty, T., Rodrigues, L., Gillotte, M., Zhang, X., BAuer Ch. and PATEl, M.K. 2017. An interdisciplinary review of energy storage for communities: Challenges and perspectives. Renewable and Sustainable Energy Reviews. Elsevier Ltd., 79(May), pp. 730-749.

PASKA, J. 2005. Electricity generation (Wytwarzanie energii elektrycznej). Warszawa: OWPW, 284 pp. (in Polish).

Prieto et al. 2018 - Prieto, C., Rodriguez, A., PAtiÑo, D. and CABEZA, L.F. 2018. Thermal energy storage evaluation in direct steam generation solar plants. Solar Energy. Elsevier, 159 (November 2016), pp. 501-509. 
SZRAMKA, R. 2001. Power generation in combination (Wytwarzanie energii w skojarzeniu). Biuletyn URE vol. 2/2001, pp. 2-4 [Online] https://www.cire.pl/publikacje/wytw_w_skojarzeniu.pdf [Accessed: 2018-05-04] (in Polish).

WoJCIECHOWSKI, H. 2017. Technologies of energy storage (Technologie magazynowania energii). Part 1, Instal 2, pp. 20-27 (in Polish).

Paweł JASTRZĘBSKI, Piotr W. SAŁUGA

\section{Symulacja wykorzystania akumulatora ciepła w elektrociepłowni}

\section{Streszczenie}

Zrównoważone zarządzanie produkcją i zużyciem energii stanowi jedno z naczelnych wyzwań XXI wieku. Wiąże się ono z zagrożeniami stanu środowiska przyrodniczego m.in. wskutek negatywnego wpływu energetyki na klimat, ograniczoności zasobów paliw kopalnych, a także niestabilności produkcji energii z wykorzystaniem źródeł odnawialnych - pomimo rozwijających się technologii pozyskania energii ze słońca, wiatru, wody, itp. W takiej sytuacji jednym ze sposobów poprawy efektywności gospodarki energetycznejzarówno w skali mikro (energetyka rozproszona), jak i makro (system elektroenergetyczny), mogą być innowacyjne rozwiązania technologiczne umożliwiające magazynowanie energii. Ich skuteczna implementacja pozwoli na jej gromadzenie w okresach nadprodukcji i wykorzystanie w sytuacjach niedoboru.

Wyzwania te są nie do przecenienia - przed współczesną nauką staje konieczność rozwiązywania różnego rodzaju zagadnień technologicznych w zakresie magazynowania, problemów organizacyjnych przedsiębiorstw wytwarzających energię elektryczną i ciepło, czy kwestii dotyczących funkcjonowania rynków energii.

W artykule przedstawiono specyfikę funkcjonowania elektrociepłowni z magazynem ciepła na rynku energii elektrycznej w odniesieniu do związanych z tym parametrów obarczonych niepewnością. Zwrócono uwagę, że istotnym elementem procesu decyzyjnego i sterowania elektrociepłownią wyposażoną w niskotemperaturowy wodny akumulator ciepła - jako systemem - jest analiza ryzyka związanego z cenami energii oraz warunkami atmosferycznymi. Złożoność zagadnień, liczba zmiennych, jakie należy przeanalizować w danym czasie skłania do zastosowania zaawansowanych metod prognozowania. Uznano, że interesującymi narzędziami, które pozwalają na prognozowanie pracy instalacji z magazynem energii z uwzględnieniem wpływu wielu zmiennych mogą być stochastyczne metody modelowania. W wyniku zrealizowanych badań pokazano, że łączne wykorzystanie symulacji Monte Carlo i prognozowania z wykorzystaniem geometrycznego ruchu Browna umożliwia kwantyfikację ryzyka działalności elektrociepłowni i wpływ zastosowania magazynu energii na rozwiązywanie niepewności. Zastosowana metodyka może zostać wykorzystana zarówno na etapie projektowania systemów z magazynami energii, jak też umożliwić bieżącą analizę ryzyka w systemach już funkcjonujących; pozwoli to na poprawę efektywności ich funkcjonowania. Wprowadzenie do analizy dodatkowych parametrów planowanych inwestycji otworzy perspektywy maksymalnego wykorzystania wielkości magazynów energii zarówno w energetyce zawodowej, jak i rozproszonej.

SŁoWA KLUCZOWE: produkcja energii, magazynowanie energii, prognozowanie zużycia, symulacja Monte Carlo 
